\title{
Environmental Traps in the Brazilian Electric Sector - A Short Note
}

Fernando Amaral de Almeida Prado*

Universidade de São Paulo, Brazil

Submission: January 25, 2019; Published: February 04, 2019

*Corresponding author: Fernando Amaral de Almeida Prado, Universidade de São Paulo, Paulo Orozimbo 675 room 101 Cambuci, Zip Code 01535001, São Paulo SP, Brazil

Keywords: Hydroelectric plants; Itaipu; Belo Monte; Tucuruí; Modality; Reservoir; Environmental issues; Indicators; Flood season

\section{Opinion}

Brazil has $162.7 \mathrm{GW}$ capacity of power plants, $64 \%$ of which are from hydroelectric plants, mostly of them are large ones (60.4\% greater than 30MW of installed capacity). The other plants are composed by wind (8.8\%), conventional thermal $(24.8 \%)$ nuclear (1.2\%), and photovoltaic (1.2\%) [1]

Due to its large rivers, Brazil has always had a tradition of building large hydroelectric, such as: Itaipu, Belo Monte, and Tucuruí; respectively, the second, third and seventh plants in the ranking of the International Committee of Large Dams - ICOLD [2].

According to the Brazilian Energy Planning Entity, there is still a great hydroelectric potential to be explored (around 160GW) with an attractive cost-benefit ratio, however mostly of them are in areas of high environmental sensitivity, notably in the Amazon region [3]. Trying to cope better with these environmental issues, since last decade the Brazilian hydroelectric power plants have had their design in the "run of a river" modality, causing a significant reduction of the storage capacity.

The Belo Monte Project, the main paradigm case of opponents of large hydroelectric in Brazil, recently in operation, has $11,233 \mathrm{MW}$ of capacity for an assured energy of 4,571MW. The huge difference between capacity and assured energy is the main consequence of reduction of storage capacity. The reservoir of this great plant corresponds to a flood area of $516 \mathrm{~km} 2$, approximately $300 \mathrm{~km} 2$ already comprised the river bed itself. In its conception phase, the Belo Monte plant had alternative studies that considered an installation of about 19,000MW (which would make it the largest plant in operation in the world), in this case the flood area would be $1,225 \mathrm{~km} 2$, but this conception did not materialize due to environmental issues [4]

The ratio of the flooded area and installed capacity for Belo Monte plant corresponds to $0.05 \mathrm{~km} 2 / \mathrm{MW}$. This figure it is below of the historical average of $0.49 \mathrm{~km} 2 / \mathrm{MW}$. These indicators highlight the prioritizing process in course now a days in Brazil for the projects of hydro power plants in a run of river way instead of a large reservoir [4].

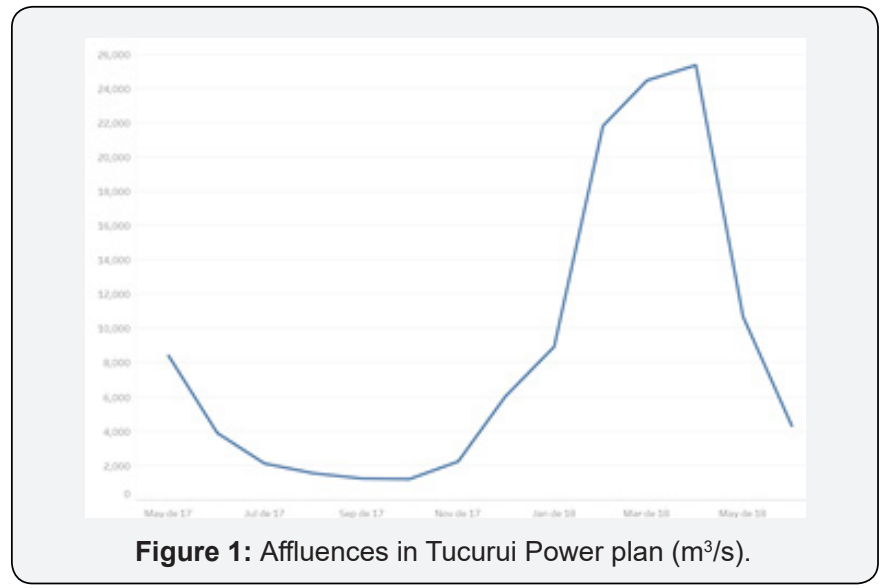

In the north region of Brazil, where remain the largest potential for new hydro's, there is a great seasonality of affluences in the rivers. Tucurui Plant is a good example of this situation. It is the third largest project in Brazil and there the difference of affluence between a dry month and a month in the flood season could more than 20 times. The figure 1 shows this evidence [5].

Another reason for prioritizing Hydro plants with reservoirs is their capacity to face the large deployment of wind power and others intermittent sources. The same concept could be applied in biomass plants that have in Brazil strong fitness with the sugar $\&$ alcohol industry from the sugar cane and consequently with a harvest period where there is enough supply of biomass. Out of the harvest period there is necessity of other solutions.

Nowadays is necessary to increase the thermal generation due to the Brazilian public policies of energy planning that eliminate "a priori " the plants with reservoirs (consequently making the hydroelectric also intermittent sources). 
It must be recorded that there is currently no analysis of the tradeoff between the energy to be produced in hydroelectric plants with reservoirs and the resulting environmental impact. Decisions occur as if the environmental costs are infinite, that is, society cannot identify whether the benefits outweigh the curses.

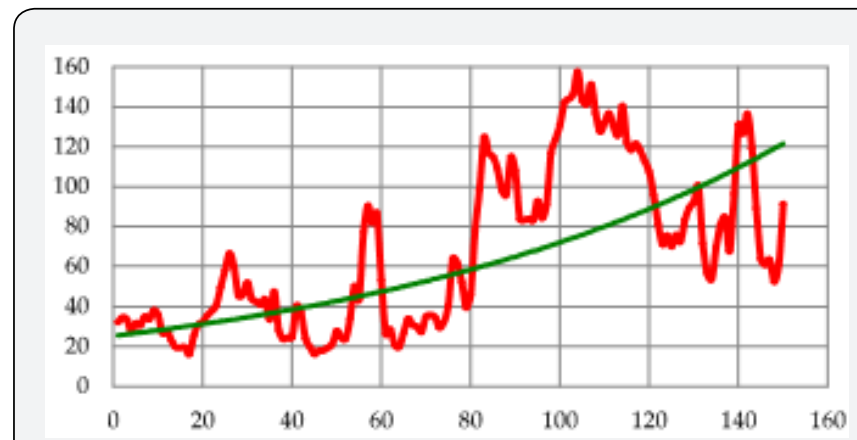

Figure 2: Emission Factors $\mathrm{kg} \mathrm{CO} / \mathrm{MWh}$-Months from January 2006 to June 2018 [6].

For this reason, there are two important impacts resulting from these choices: economic and environmental. In the first case, hydroelectric plants are often prevented from operating by decisions of the Independent System Operator -ISO who prefers to store water at older plants that still have reservoirs to increase system safety in the future, so hydro's even with water reserves are prevented from operating (the operating system in Brazil is deterministic). For meeting trade commitments, they need to buy energy in the spot market whose price is aligned with the most expensive thermal dispatched in the week, often at prices high above those that were sold. There is an inevitably landslide of lawsuits that undermines market liquidity. It is estimated that there are about US $\$ 3$ billion in lawsuits, only in the cases of mandatory reduction of capacity ordered by the ISO regulation.

In the environmental field, the volatility of the intermittent plants is aggravated by the lack of capacity to regularize the flows of the new hydroelectric plants has promoted the increase of greenhouse gas emissions from the electric power industry. Figure 2 shows this trend [6].

The choices regarding environmental protection related to the "a priori" disposal of hydroelectric plants with reservoirs

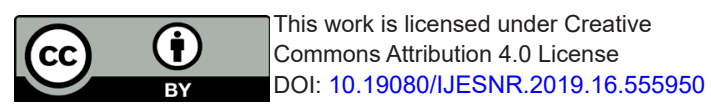

ends up becoming a trap in energy policies, producing transverse environmental impacts and increasing costs that will impact future tariffs.

Denying socio-environmental impacts in the construction of large hydroelectric dams is not a defensible position, however, Brazil lacks initiatives to discuss these impacts in a broader perspective considering a cost and benefit accounting for society. The author argue that large hydroelectric plants can provide net benefits to society, although it is clear that there will be impacted agents. Part of these benefits are important because of the increased possibilities for the insertion of intermittent sources with their environmental and economic benefits.

The analysis of the use of water resources to produce electricity is in fact a discussion about the use of natural resources (public goods) and how the income associated with these uses is shared among the whole society and how they contribute to finance the economic development of one Nation.

If we consider that major works do not result in neutral positions, it is important to emphasize that the monitoring and enforcement of the assumed commitments of socio-environmental mitigation and compensation should be better executed, especially in Brazil.

This small communication argues that large hydropower should be reconsidered in the Brazilian energy policy, but always with a view to compensating those impacted by avoiding the damages caused by the traps.

\section{References}

1. ANEEL- Agência Nacional de Energia Elétrica. Boletim de informações de Geraçao.

2. ICOLD- International Committee of Large Dams.

3. EPE- Empresa de Planejamento Energético. Plano Decenal de Expansão 2018- 2027.

4. EPE-Empresa de Pesquisa Energética. Projeto da usina hidrelétrica de Belo Monte. Fatos e dados.

5. ONS-Operador Nacional do Sistema Elétrico. Resultados da operação.

6. MCTI- Ministério da Ciência, Tecnologia, Inovaçao e Comunicação.

\section{Your next submission with Juniper Publishers will reach you the below assets}

- Quality Editorial service

- Swift Peer Review

- Reprints availability

- E-prints Service

- Manuscript Podcast for convenient understanding

- Global attainment for your research

- Manuscript accessibility in different formats

( Pdf, E-pub, Full Text, Audio)

- Unceasing customer service

Track the below URL for one-step submission https://juniperpublishers.com/online-submission.php 